JURNAL 『EKRNOSAINS

VOLUME 1

No. 1, 22 Desember 2011

Halaman 1-69

\title{
Pipeline Program CDM di Indonesia: Sebuah Peluang dan Tantangan Untuk Industri Pertambangan
}

\author{
Joni Safaat Adiansyah \\ Fakultas Teknik Program Studi Pertambangan Universitas Muhammadiyah Mataram \\ Email: joni.adiansyah@gmail.com
}

\begin{abstract}
Climate change is one of the world's problems that must be dealt; the failure in tackling climate change will impact on increasing the earth temperature and endanger the archipelago countries including Indonesia. Clean Development Mechanism (CDM) is one of the Kyoto Protocol mechanisms designed to mitigate climate change. Indonesia is one of the countries that meets the requirement as the host of CDM program and has set up the target to reduce GHG emissions as much as 26 percent in year 2020. The industrial sector has opportunities to engage actively in reducing GHG emission including mining industry. The objectives of this research are to find out the potency of mining company's involvement in climate change mitigation efforts particularly through CDM. In addition, the research of method that is chosen is literature study including reviewing data relating to CDM and with qualitative approached. The result shows that mining industry has a potency to involve actively in CDM program, among others, through energy efficiency, fuel substitution, renewable energy, Coal Bed Methane and the handling of critical lands through afforestation and reforestation scheme. Furthermore, by using Business as Usual assumption, the linier regression that is produced $y=27.255 . x+12.711$ therefore It is estimated that about $15 \mathrm{Mt}$ CO2-e (assuming 4 percent reduction) needs to be derived from the energy sector in 2020 that can be taken as an opportunity for the mining industry as well.
\end{abstract}

Keyword: Clean Development Mechanism, Industri Pertambangan, Kyoto Protocol, Emisi, Sektor Energi.

\begin{abstract}
ABSTRAK
Perubahan iklim adalah salah satu permasalahan dunia yang harus ditangani secara bersama, kegagalan dalam penanganan perubahan iklim akan berimbas pada peningkatan suhu bumi dan membahayakan negara-negara kepulauan khususnya termasuk Indonesia. Clean Development Mecahnism (CDM) adalah salah satu mekanisme dari Kyoto Protocol (KP) yang dirancang untuk melakukan mitigasi perubahan iklim. Indonesia adalah salah satu Negara yang memenuhi persyaratan sebagai tuan rumah pelaksanaan program CDM dan menargetkan untuk mengurangi emisi GHG sebanyak 26 persen pada Tahun 2020. Sektor Industri mempunyai peluang terlibat aktif dalam penurunan emisi GHG termasuk pertambangan. Tujuan dilakukan penelitian adalah antara lain untuk melihat sejauh mana potensi terhadap keterlibatan perusahaan tambang dalam upaya mitigasi perubahan iklim khususnya melalui program CDM. Adapun metode penelitian dilakukan melalui studi pustaka termasuk mengkaji data-data yang berkaitan dengan CDM dan dengan pendekatan kualitatif. Dari pendekatan tersebut didapatkan hasil bahwa perusahaan pertambangan mempunyai potensi untuk terlibat dalam program CDM antara lain melalui proyek energi efisiensi, penggantian bahan bakar, pemanfaatan energi terbarukan, Coal
\end{abstract}


Bed Methane (CBM) dan penanganan lahan kritis melalui skema Afforestation dan Reforestation. Lebih lanjut dengan menggunakan asumsi Business as Usual (BAU) diperoleh persamaan regresi $y=27.255 . x+12.711$ sehingga diperkirakan sekitar $15 \mathrm{Mt} \mathrm{CO}_{2}$-e (asumsi 4 persen) perlu diturunkan dari sektor energi (peluang juga bagi industri pertambangan) pada Tahun 2020.

Kata Kunci: Clean Development Mechanism, Industri Pertambangan, Kyoto Protocol, Emisi, Sektor Energi.

\section{PENGANTAR}

Perubahan iklim merupakan salah satu isu lingkungan global yang paling sering dibicarakan dan didiskusikan di seluruh dunia. Hal ini ditandai dengan adanya Persetujuan Multilateral terkait dengan upaya penanganan perubahan iklim. Puncaknya dengan disetujuinya Kyoto Protocol (KP) yang memuat skema-skema mitigasi perubahan iklim dengan berupaya menurunkan emisi Greenhouse Gas (GHG). Ada3 (tiga) mekanisme fleksibel yang dijalankan KP yaitu Emission Trading (ET), Joint Implementation (JI), dan Clean Development Mechanism (CDM). CDM sebagai salah satu mekanisme mempunyai tujuan ganda yaitu menurunkan emisi karbon dan menciptakan pembangunan berkelanjutan di Negara tempat implementasi program.

Salah satu Negara yang telah meratifikasi KP pada tahun 2004 dan memiliki Designated National Auhtority (DNA) yang bertugas mengelola program CDM di Indonesia, maka Indonesia telah memenuhi persyaratan sebagai tuan rumah pelaksanaan program CDM. Selain itu, Indonesia yang memiliki ciri negara kepulauan sangatlah rentan terhadap dampak dari perubahan iklim sehingga tidak mengherankan jika Pemerintah Republik Indonesia (RI) berkomitmen menurunkan emisi GHG sebanyak 26 persen pada tahun 2020 (Verchot dkk., 2010). Sebagai Negara kepulauan, maka kenaikan muka air laut yang disebabkan oleh perubahan iklim dan mengakibatkan hilangnya pulau-pulau di Indonesia akan sangat mungkin dialami. Apalagi hal ini didukung dengan permodelan yang dituangkan dalam laporan IPCC 2007 yang memprediksi kenaikan suhu sampai 4 derajat pada tahun 2100 jika permasalah perubahan iklim tidak ditangani secara komprehensif.

Dengan demikian tidaklah mengherankan jika Indonesia terlibat aktif dalam melakukan mitigasi perubahan iklim melalui berbagai sektor. Penyumbang emisi terbesar di Indonesia seperti yang ditampilkan pada Grafik 2 adalah sektor kehutanan (LULUCF) dan diikuti dengan sektor energi. Sektor industri termasuk pertambangan khususnya menyumbangkanemisiGHGdaripenggunaan bahan bakar fosil dan diperkirakan pada tahun 2030 emisi dari penggunaaan bahan bakar fosil akan meningkat 4 kali lebih tinggi dibanding saat ini (Haeni dkk., 2008). Dengan demikian, kontribusi dunia industri termasuk pertambangan untuk berperan dalam mitigasi perubahan iklim akan sangat terbuka khususnya dalam mensukses target RI dalam menurunkan emisi GHG. Selain itu mitigasi perubahan iklim melalui CDM akan memberikan ruang terbuka pula bagi industri termasuk pertambangan untuk mengombinasikan konsep-konsep Sustainable Development (SD) dengan program Corporate Social Responsibility (CSR).

Peluang keterlibatan perusahaan pertambangan dalam mitigasi perubahan iklim tersebut perlu dikaji lebih lanjut sehingga diperoleh gambaran tentang potensi emisi GHG di Indonesia dikaitkan dengan target serta peran perusahaan pertambangan dan potensi emisi GHG didapatkan dengan melakukan peramalan metode regresi. Dengan diperoleh indikasi peluang tersebut, maka pemerintah dan perusahaan pertambangan bisa merumuskan strategi dasar untuk memainkan peran secara aktif dalam mitigasi perubahan iklim di Indonesia.

Penelitian adalah salah satu cara untuk mendapatkan jawaban dari sebuah pertanyaan. Artinya bahwa penelitian merupakan sebuah aktivitas yang melibatkan beberapa proses termasuk menentukan 
JONI SAFAAT ADIANSYAH PIPELINE PROGRAM CDM DI INDONESIA: SEBUAH PELUANG DAN TANTANGAN UNTUK INDUSTRI PERTAMBANGAN

framework, metode, dan teknik (Kumar, 2005). Oleh karena itu, penelitian perlu ditentukan metode penelitian yang mengarahkan menuju suatu jawaban secara sistematik.

Adapun metode penelitian dilakukan melalui studi pustaka termasuk mengkaji datadata yang berkaitan dengan CDM dan aktivitas perusahaaan pertambangan di Indonesia. Pendekatan yang digunakan lebih kepada pendekatan kualitatif dengan ditunjang oleh data-data yang relevan. Analisa regresi linier sederhana digunakan untuk melakukan peramalan terhadap potensi emisi GHG dari sektor energi pada tahun 2020.

\section{PEMBAHASAN}

Terbentuknya DNA Indonesia yang bernama Komisi Nasional Mekanisme Pembangunan Bersih (KNMPB) pada tahun 2005 merupakan tonggak awal mulainya proyek CDM di Indonesia. Diawali dengan keikutsertaan Indonesia dalam penandatanganan KP pada tahun 1998 dan diikuti dengan proses ratifikasi pada tahun 2004 sehingga memungkinkan Indonesia menjadi salah satu host untuk program CDM ( Napitupulu dkk., 2005).

Sejak awal berdirinya, DNA Indonesia telah menyetujui sebanyak 133 proyek CDM yang tersebar di beberapa pulau di Indonesia yaitu Sumatra, Jawa, Kalimantan, Sulawesi, dan Bali. Pada tabel 1 dari total proyek CDM yang telah disetujui oleh DNA Indonesia sejumlah $47 \%$ telah teregistrasi di CDM Executive Board UNFCCC (IGES, 2011).

Tabel 1.

Status Proyek CDM di Indonesia (per 31 Maret 2011)

\begin{tabular}{|l|l|}
\hline \multicolumn{1}{|c|}{ Status Proyek } & Jumlah Proyek \\
\hline $\begin{array}{l}\text { Proyek CDM teregistrasi di } \\
\text { CDM Executive Board }\end{array}$ & 62 \\
\hline $\begin{array}{l}\text { Proyek CDM disetujui oleh } \\
\text { DNA Indonesia }\end{array}$ & 133 \\
\hline $\begin{array}{l}\text { Proyek CDM dalam proses } \\
\text { validasi }\end{array}$ & 44 \\
\hline
\end{tabular}

Namun demikian dari total proyek CDM yang telah teregistrasi di CDM Executive Board pulau Sumatra dan Jawa masih mendominasi keberadaan proyek CDM dengan masingmasing 37 proyek (60\%) dan 17 proyek $(27 \%)$. Selain itu, secara umum bisa dikatakan bahwa setiap tahun terjadi peningkatan jumlah proyek CDM di Indonesia dari total Emission Reduction (ER) sampai dengan tahun 2012 dari 62 proyek CDM yang telah teregistrasi di CDM Executive Board diperkirakan berjumlah 26.398.358 ton $\mathrm{CO}_{2}$-e (IGES, 2011). Dari total ER tersebut industri semen menyumbangkan ER paling besar sekitar 7.192.609 ton $\mathrm{CO}_{2}$-e kemudian diikuti oleh energi terbarukan lain dan biogas seperti yang ditampilkan pada Grafik 1.

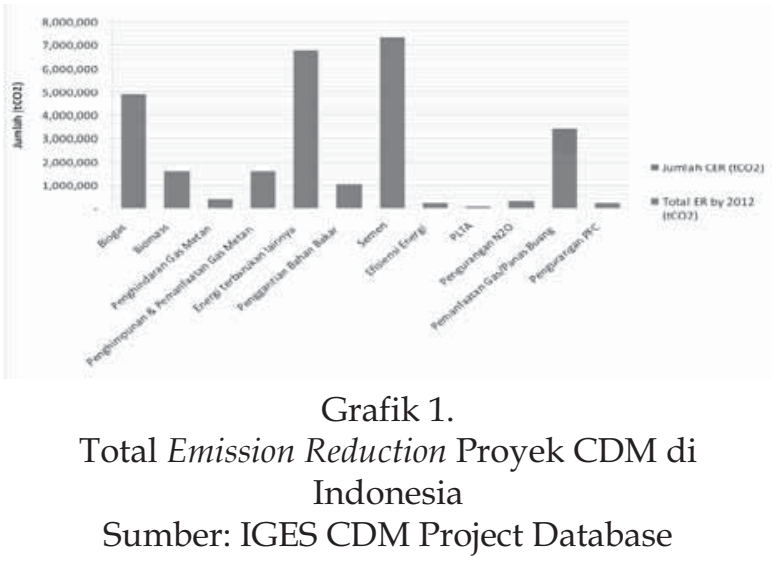

Lebih jauh, sekitar 12 tipe proyek CDM berkembang di Indonesia antara lain penghimpunan dan pemanfaatan gas metan, biogas, biomass, dan energi terbarukan. Jika mengacu pada jenis proyek CDM tersebut, maka sebenarnya beberapa jenis proyek bisa diikuti oleh perusahaan pertambangan antara lain efisiensi energi, penggantian bahan bakar, dan energi terbarukan. Pada Tabel 2 bahwa secara berkala jumlah dan jenis proyek CDM di Indonesia terus bertambah. Hal ini tentu tidak terlepas dari peran DNA Indonesia, Pemerintah, Masyarakat maupun dunia industri selaku stakeholder proyek CDM. 
Tabel 2.

Tipe/Jenis Proyek CDM di Indonesia (per 31 Maret 2011)

\begin{tabular}{|l|l|l|l|l|l|l|l|l|}
\hline \multicolumn{1}{|c|}{ Tipe Proyek/Tahun } & $\mathbf{2 0 0 5}$ & $\mathbf{2 0 0 6}$ & $\mathbf{2 0 0 7}$ & $\mathbf{2 0 0 8}$ & $\mathbf{2 0 0 9}$ & $\mathbf{2 0 1 0}$ & $\mathbf{2 0 1 1}$ & Total \\
\hline $\begin{array}{l}\text { Penghimpunan \& Pemanfaatan } \\
\text { Gas Metan }\end{array}$ & - & 2 & 2 & 9 & 9 & 9 & 1 & 32 \\
\hline Penghindaran Gas Metan & - & - & - & 11 & 5 & 3 & 1 & 20 \\
\hline Biomass & 2 & - & 4 & 6 & 3 & 2 & - & 17 \\
\hline Penggantian Bahan Bakar & - & 1 & 2 & 6 & 3 & - & - & 12 \\
\hline PLTA & - & - & 2 & 3 & 1 & 5 & 1 & 12 \\
\hline Biogas & - & 1 & - & 4 & 6 & - & - & 11 \\
\hline Energi Terbarukan lainnya & 1 & 1 & & 2 & 3 & 2 & & 9 \\
\hline Pemanfaatan Panas/ Gas Buang & - & 1 & 1 & 2 & 3 & - & 1 & 8 \\
\hline Efisiensi Energy & - & - & - & 2 & 1 & 3 & - & 6 \\
\hline Semen & 2 & - & 1 & - & - & 1 & - & 4 \\
\hline Pengurangan PFC & - & - & - & 1 & - & - & - & 1 \\
\hline Pengurangan $\mathrm{N}_{2} \mathrm{O}$ & - & - & 1 & - & - & - & - & \\
\hline Total & 5 & 6 & 13 & 46 & 34 & 25 & 4 & 133 \\
\hline
\end{tabular}

Sumber: KNMPB dan DNPI, 2011

Setiap stakeholder memegang peranan penting terhadap perkembangan proyek CDM. Setiap stakeholder memainkan peranan masing-masing baik selaku regulator, pelaku maupun pengagas proyek. Keterlibatan setiap stakeholder dalam sebuah proyek CDM akan menentukan pula keefektifan dan keberhasilan sebuah proyek CDM. Salah satu penilaian keefektifan sebuah proyek CDM berdasarkan kriteria sustainable development (SD) termasuk keterlibatan stakholder dipaparkan dalam Adiansyah (2008) yang menyebutkan bahwa keterlibatan masyarakat selaku salah satu stakeholder memberikan nilai lebih untuk sebuah proyek CDM.

Salah satu peran yang dimainkan oleh stakeholder adalah selaku Pengagas Proyek. Dari proyek CDM di Indonesia terlihat bahwa pemrakarsa setiap proyek berasal dari berbagai macam sektor baik industri, lembaga, maupun pemerintah. Dengan demikian bisa dikatakan bahwa proyek CDM mempunyai pemrakarsa yang beragam. Namun demikian jika melihat tipe proyek CDM yang berkembang bisa dipastikan bahwa industri memegang peranan terbesar yaitu lebih dari 80 persen dari total proyek.

\section{Peluang}

Potensi terhadap proyek CDM telah diidentifikasi sejak tahun 2001 yang dituangkan dalam laporan National Strategy Study (NSS) on the Clean Development Mechanism in Indonesia. Beberapa aspek yang masuk ke dalam pertimbangan laporan tersebut adalah seperti konsumsi energi, prospek pasar, dan kemungkinan Indonesia menjadi 'host' proyek CDM. Secara ringkas, laporan tersebut mengungkap bahwa potensi Indonesia dalam menjalankan proyek CDM berkisar antara 2 sampai 6 persen dari pasar global (KLH, 2002).

Dalam laporan NSS maupun grafik 2 terlihat bahwa trend emisi baik di Indonesia maupun ASEAN mempunyai pola yang sama didominasi oleh sektor kehutanan dan energi. Total emisi GHG Indonesia pada tahun 2005 adalah sekitar 2 yaitu total emisi mengacu pada emisi dari delapan sektor termasuk LULUCF, gambut, pertanian, transportasi, tenaga listrik, bahan bakar minyak dan pengolahan, semen, dan bangunan. Giga ton (Gt), yaitu satu Giga ton (Gt) setara dengan satu milliar ton (DNPI, 2010, CAIT:WRI, 2011) dengan komposisi dari sektor kehutanan sebesar 71,4 
persen, kemudian diikuti dengan sektor energi sebesar 19,5 persen atau sekitar 398 Juta ton$\mathrm{CO}_{2} \mathrm{e}$ di dalamnya terdiri dari kelistrikan, pabrik dan konstruksi, transportasi, dan pembakaran bahan bakar lainnya. Lebih lanjut, diproyeksikan emisi GHG di Indonesia akan meningkat sampai dengan 3,2 Gt pada tahun 2030 atau 4,5 persen dari total emisi GHG global untuk skenario bisnis seperti biasa (business as usual) (DNPI, 2010).

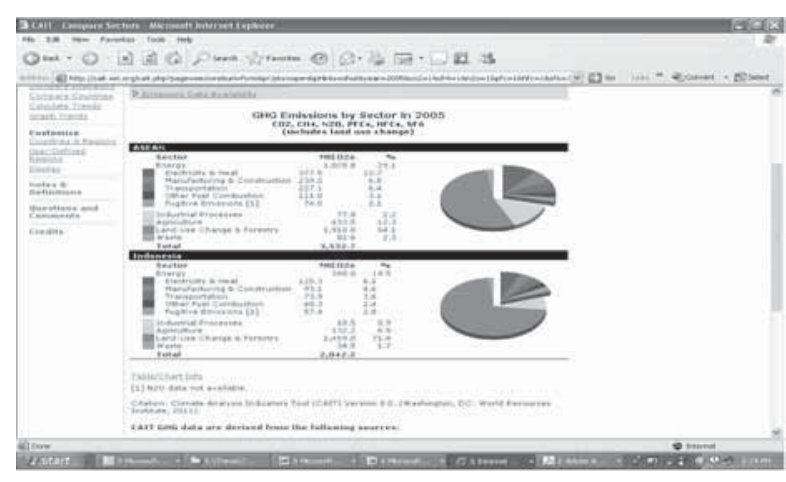

\section{Grafik 2.}

Emisi GHG berdasarkan Sektor Tahun 2005

Sumber: Climate Analysis Indicators Tool (CAIT) version 8.0, http:// cait.wri.org

Dengan demikian dapat dikatakan bahwa jika tidak dilakukan usaha pengurangan emisi maka Indonesia diperkirakan akan menjadi salah satu emitter terbesar baik dari sektor kehutanan maupun energi. Emisi yang dihasilkan dari sektor energi merupakan kontribusi dari pembakaran bahan bakar fosil. Oleh karena itu, beberapa opsi diajukan dalam menurunkan emisi GHG dari sektor energi antara lain mengurangi penggunaan bahan bakar carbon dan menggantikan dengan non-carbon atau bahan bakar rendah carbon, meningkatkan efisiensi pembakaran dan mengurangi kebocoran gas metan (MoE Japan dkk., 2006)

\section{Pertambangan dan CDM}

The International Council of Mining and Metals telah mengidentifikasi bahwa perubahan iklim khususnya dampak dari GHG sebagai isu lingkungan paling penting yang tidak dapat dipungkiri pula dihadapi oleh perusahaan tambang (Hendrickson dan Venalainen, 2008). Beberapa kegiatan dari pertambangan memberikan sumbangan terhadap konsentrasi GHG di atmosfer antara lain pembangkit listrik, transportasi, perumahan, dan pengelolaan sampah. Dari kegiatan-kegiatan tersebut maka bisa dipastikan bahwa keberadaan pembangkit listrik dengan sumber carbon fuel akan memberikan sumbangan emisi terbesar dari sebuah kegiatan pertambangan.

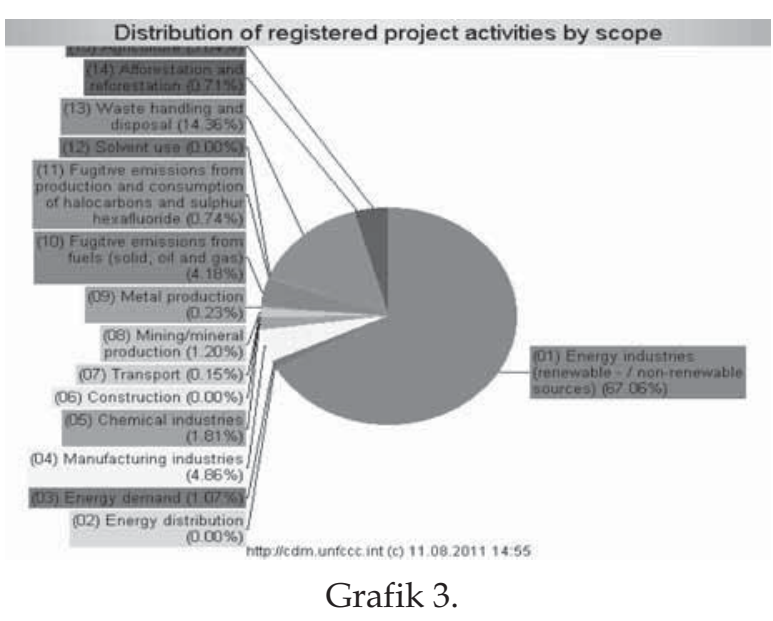

Distribusi Proyek CDM sesuai Scope

Sumber: UNFCCC, 2011, http://cdm.unfccc.int

Saat ini dari total 3.348 proyek CDM yang terdaftar di CDM Executive Board sekitar 1,2 persen berkaitan langsung dengan pertambangan, dimana prosentase proyek terbesar adalah sektor energi sejumlah 67,06 persen (lihat grafik 3). Diperkirakan dari total proyek CDM tersebut akan menghasilkan CER rata-rata tahunan sejumlah $499 \mathrm{Mt} \mathrm{CO}_{2}$-e. Lebih lanjut, walaupun berbagai tipe CDM proyek memungkinkan untuk perusahaan pertambangan namun saat ini yang paling umum dan populer adalah berkaitan dengan Coal Bed Methane (CBM). Selain itu keberadaan methologi (ACM 0002 dan ACM 0008) yang sudah baku di CDM Executive Board memudahkan untuk menjalankan CBM melalui mekanisme CDM. Beberapa contoh proyek CBM dilakukan antara lain di China 
oleh the Yangquan Coal Industry (Group) dan Australia oleh Appin \& Tower Power Plants (Hendrickson dan Venalainen, 2008). Kedua perusahaan tersebut memanfaatkan gas methan yang di salurkan dari kedalaman lebih dari 1.000 meter di bawah permukaan tanah dan gas methan yang dihasilkan dimanfaatkan untuk pembangkit listrik. Di Indonesia sendiri sudah mulai berkembang CBM, yaitu produksi pertama akan dihasilkan dari proyek CBM di Sangatta dengan operator BP Migas (ESDM, 2011). Potensi sumberdaya CBM di Indonesia yang dikeluarkan oleh Direktorat Jenderal Minyak dan Gas Bumi adalah sekitar 450 Tcf (Trillion Cubic Feet). Jika dicermati perusahaan pertambangan khususnya batubara dapat melakukan pengelolaan terhadap gas methan yang dihasilkan dan menghasilkan multiple revenue seperti penjualan carbon dan pemanfaatan energi. Contoh keterlibatan perusahaan pertambangan yang memungkinkan untuk dimasukkan dalam skema CDM (khusus untuk Negara Non-Annex I) adalah seperti apa yang dilakukan oleh Anglo American's Highveld Steel's Transalloys melalui energi efisiensi (diperkirakan mengurangi $98 \mathrm{kt}$ $\mathrm{CO}_{2}$-e) dan Mondi Richard Bay's melalui subtitusi bahan bakar dengan biomass (diperkirakan mengurangi $122 \mathrm{kt} \mathrm{CO}_{2}$-e) (Hendrickson dan Venalainen, 2008).

Jika dicermati lebih dalam seperti disajikan pada Grafik 4 (KLH, 2009) terlihat bahwa dari tahun ke tahun kontribusi GHG dari sektor energi meningkat secara bertahap. Pada kondisi Business as Usual (BAU) dengan menggunakan persamaan regresi $\mathrm{y}=27.255$. $\mathrm{x}$ + 12.711, diperkirakan pada Tahun 2020 sumbagan emisi sebesar 944.767 Gg CO2-e. Dengan mengambil nilai asumsi penurunan sebesar 4 persen dari baseline emission Tahun 2010, maka diperkirakan potensi penurunan sektor energi sebesar 15 Juta ton CO2-e. Hal ini merupakan sebuah peluang bagi perusahaan pertambangan untuk ikut ambil bagian dari target penurunan emisi ters

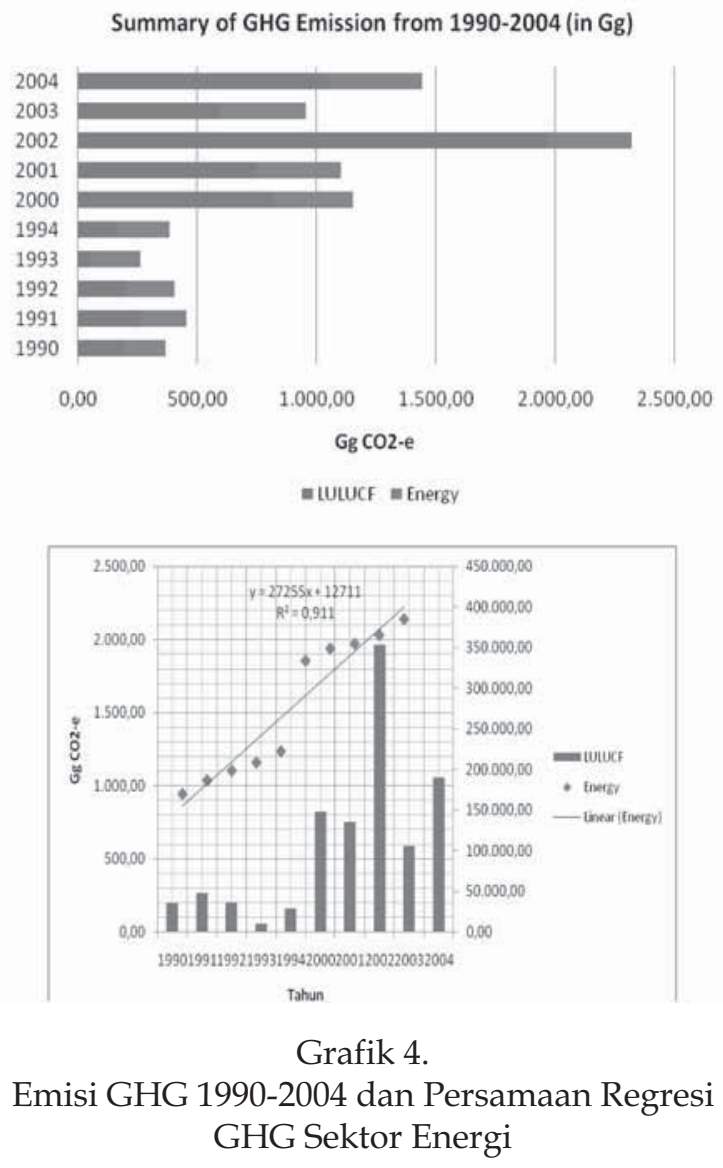

Dari biaya teknis yang diketahui dan biaya teknologi pengurangan yang tersedia saat ini diperkirakan rata-rata biaya pengurangan emisi per-ton $\mathrm{CO}_{2}$-e di Indonesia adalah sekitar 2 USD (DNPI, 2010) yaitu rata-rata harga carbon dipasaran dunia berkisar 10 - 15 USD/ton. Biaya pengurangan tersebut merupakan salah satu penghalang bagi perusahaan yang ingin terlibat dalam mitigasi perubahan iklim karena akan menambah biaya (cost) perusahaan. Namun demikian dengan melakukan proyek CDM maka beberapa penghalang bisa dihindari termasuk financial barier. Beberapa lembaga dunia termasuk world bank menyediakan skema khusus untuk membiayai proyek CDM. Selain itu beberapa lembaga lain seperti Carbon Fund, Asia Carbon, South Pole, The Climate Change Technology Fund, Asian Development Bank juga mempunyai skema khusus untuk proyek CDM termasuk 
memberikan asistensi terhadap penyiapan dokumen CDM.

\section{Pertambangan, CDM, dan Corporate Social Responsibility (CSR)}

Dalam melakukan aktivitas pertambangan, setiap perusahaan tambang mempunyai kewajiban untuk melakukan apa yang disebut dengan Corporate Social Responsibility (CSR). Berbagai macam tambang mempunyai program tersendiri terkait dengan CSR, hal ini tentunya disesuaikan dengan kebutuhan masyarakat di sekitarnya. Salah satu contoh PT Newmont Nusa Tenggara melakukan CSR dengan mengedepankan beberapa pilar program antara lain Pendidikan, Kesehatan, Ekonomi, dan Infrastrukur (PTNNT, 2009). Jika diamati lebih lanjut bahwa semua program CSR diharapkan menjadi program berkelanjutan (sustainable development) sehingga bisa menciptakan masyarakat yang mandiri pasca tambang.

Terkait dengan hal tersebut, maka terjadi keterkaitan yang sangat erat antara CSR yang dijalankan oleh perusahaan pertambangan dengan program CDM. Indikator yang menjadi benang merah diantara keduanya adalah konsep sustainable development diimplementasikan oleh keduanya. CDM sendiri menjalankan dua target besar yaitu menurunkan emisi karbon dan menciptakan sustainable development (SD) di negara 'host' CDM. Keterkaitan CDM denganSD dibuktikan dengan dilakukan analisa keterkaitan dua proyek CDM dengan SD (Adiansyah, 2008). Kedua proyek CDM yang dianalisa berdasarkan indikator SD yang ditetapkan oleh DNA Indonesia yaitu aspek lingkungan, aspek ekonomi, aspek sosial, dan aspek teknologi. Kedua proyek tersebut, kompor matahari di Aceh Tenggara, dan penggunaan bahan bakar alternatif di Indonecement menunjukkan bahwa tercapainya misi SD dalam proyek CDM walaupun dalam takaran yang bervariasi untuk setiap indikator (Adiansyah, 2008). Bervariasinya tingkat SD di setiap proyek CDM banyak ditentukan oleh keterlibatan stakeholder, keterlibatan masyarakat secara aktif akan meningkatkan nilai SD dari sebuah proyek CDM.

DenganadanyakonsepSD didalamindustri pertambangan maupun CDM, maka secara langsung perusahaan tambang yang melakukan proyek CDM telah juga melakukan program CSR. Lebih lanjut, sinergi atau pengabungan keduanya memberikan nilai manfaat pula dari sisi ekonomi selain company image dalam bidang perubahan iklim (Climate Change).

\section{Tantangan}

Pelaksanaan proyek CDM di Indonesia bukan tanpa kendala apalagi dikaitkan dengan belum adanya perusahaan pertambangan yang terlibat dalam proyek CDM. Sedangkan jika melihat pada sejumlah proyek CDM yang telah teregistrasi di CDM Executive Board maka peluang keterlibatan perusahaan tambang sangat besar seperti disajikan dalam Grafik 3. Hal ini dapat disebabkan oleh beberapa hal antara lain skema CDM yang tidak menarik, ketersediaan peraturan yang mendukung, dan keefektifan lembaga DNA selaku regulator proyek CDM di Indonesia.

Salah satu tantangan dalam menarik perusahaan pertambang untuk terlibat aktif dalam proyek CDM adalah komitmen dari perusahaan pertambangan untuk mengikuti serangkaian proses yang dimulai dari penyusunan Project Design Document (PDD) sampai dengan dikeluarkannya CER oleh CDM Executive Board. Secara umum serangkaian proses tersebut seperti diterlihat pada Gambar 1.

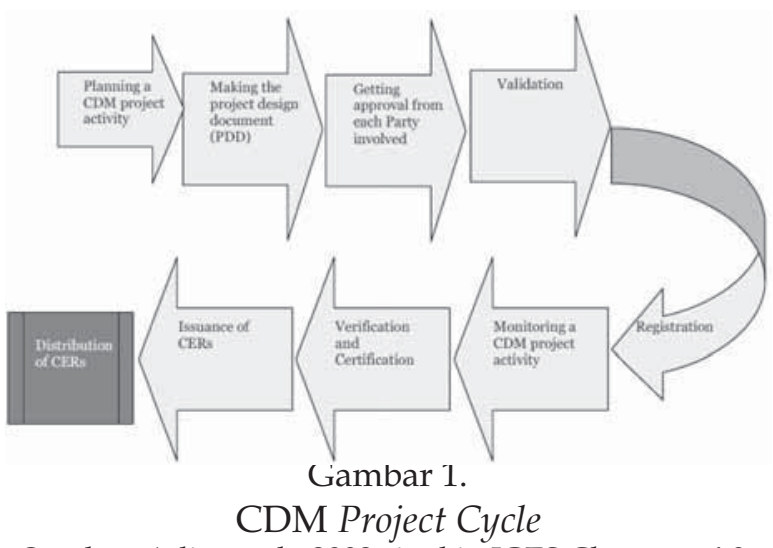

Sumber: Adiansyah, 2008 cited in IGES Chart ver.6.0, 2008 (modified) 
Keengangan yang sering ditemui terhadap para pihak yang ingin terlibat dalam proyek CDM adalah diperlukan waktu dan komitmen untuk mendapatkan apa yang disebut CER. Akan tetapi, CER yang dihasilkan akan bisa mengantikan 'pengeluaran' para pihak yang terlibat dalam proyek CDM.

Selain itu tantangan yang muncul tidak hanya berasal dari perusahaan pertambangan, tetapi juga dari pemerintah selaku regulator. Saat ini belum ada regulasi yang mendorong perusahaan pertambangan untuk bisa terlibat aktif dalam proyek CDM. Salah satu regulasi yang bisa menarik perusahaan pertambangan untuk berperan dalam proyek CDM adalah penerbitan skema pengurangan pajak atau insentif bagi perusahaan yang menggunakan teknologi ramah lingkungan.

Lebih lanjut, keberadaan regulasi yang ada masih memerlukan penjabaran lebih lanjut seperti PP Nomor 76 Tahun 2008 tentang Rehabilitasi dan Reklamasi Hutan. Penjabaran yang dimaksud disini adalah diperlukannya regulasi pendukung di bawahnya sehingga para pihak akan mempunyai payung hukum dalam menjalankan sebuah program khususnya terkait dengan program perubahan iklim. Sebagai ilustrasi di dalam PP No.76/2008 dibuka kesempatan untuk melakukan kegiatan rehabilitasi di luar kawasan hutan termasuk di semua lahan kritis. Hal ini dapat dilakukan perusahaan pertambangan namun untuk lebih menarik, maka perlu di 'koneksi' dengan skema perubahan iklim seperti CDM Afforestation/Reforestation (CDM A/R) atau REDD+ (Reduction Emission from Deforestation and Forest Degradation). Untuk bisa melakukan koneksi tersebut, maka peran pemerintah selaku regulator sangat dibutuhkan. Kemudian yang perlu juga menjadi perhatian pemerintah adalah penguatan kelembagaan baik dari sisi financial maupun sumber daya dari DNA Indonesia sehingga informasi mengenai proyek CDM bisa disampaikan secara terstruktur dengan melibatkan lebih banyak pihak termasuk perusahaan pertambangan.

\section{SIMPULAN}

Peluang terbuka lebar untuk perusahaan pertambangan terlibat aktif dalam mitigasi perubahan iklim termasuk melalui proyek CDM. Beberapa proyek CDM yang dapat dijalankan perusahaan pertambangan antara lain efisiensi energi, pemanfaatan energi terbarukan, penggunaan bahan bakar alternatif, dan Afforestation and Reforestation. Namun demikian proyek yang berkaitan dengan energi yang memiliki peluang paling besar untuk dijalankan. Seperti diketahui bahwa emisi yang harus diturunkan dari sektor energi diperkirakan sebesar 15 Juta ton $\mathrm{CO}_{2}$-e pada Tahun 2020 dengan asumsi 4 persen dari total kenaikan emisi sektor energi pada periode 2010-2020.

Selain itu dengan menjalankan proyek CDM, maka perusahaan pertambangan akan secara langsung pula dapat mengimplemetasikan program CSR yang berkelanjutan. Hal ini dimungkinkan karena proyek CDM membawa salah satu misi yaitu terciptanya sustainable development di negara 'host' CDM.

Lebih lanjut, peran dari perusahaan pertambangan untuk terlibat dalam proyek CDM di Indonesia perlu ditingkatkan karena potensi yang dimiliki Indonesia cukup besar salah satunya adalah Coal Bed Methane (CBM). Peningkatan peran dan keterlibatan perusahaan pertambangan perlu didukung oleh Pemerintah selaku regulator dengan menerbitkan peraturan-peraturan yang relevan. Dengan keberadaan peraturan maka perusahaan pertambangan mempunyai payung hukum untuk terlibat lebih jauh ke dalam program mitigasi perubahan iklim pada umumnya dan CDM khsusunya. Peraturan berupa pemotongan pajak atau insentif untuk penggunaan produksi ramah lingkungan serta mendorong perusahaan pertambangan untuk ambil bagian dalam CDM A/R maupun skema REDD+ melalui 
rehabilitasi lahan kritis yang luasnya lebih dari 59 Juta Hektar (Verchot et.al, 2010) di Indonesia.

Tentunya keterlibatan perusahaan pertambangan dalam menurunkan emisi karbon dalam target penurunan emisi Indonesia di Tahun 2020 sebesar 26 persen akan mendekati kenyataan dengan dukungan penuh dari Pemerintah walaupun sumbangan penurunan emisi perusahaan pertambangan jauh di bawah sektor LULUCF (penghasil emisi GHG terbesar) yang ditargetkan sebesar lebih dari 55 persen dari total emisi.

\section{DAFTAR PUSTAKA}

Adiansyah, J.S., 2008, "The Evaluation of Climate Change Regime, Clean Development Mechanism, in Indonesia, Wageningen University, The Netherlands.

Climate Analysis Indicators Tool (CAIT) version 8.0., 2011, World Resources Institute, Washington DC, http:// cait.wri.org, Accessed 10 July 2011.

Dewan Nasional Perubahan Iklim (DNPI), 2010, “Kurva Biaya (Cost Curve) Pengurangan Gas Rumah Kaca Indonesia, DNPI, Jakarta.

ESDM, 2011, http:/ / www.esdm.go.id, Accessed 16 August 2011.

Haeni, J.H., C.Green., E. Setianto., 2008, "Indonesia Energy Assessment", USAID, Jakarta.

Hendrickson, B., M. Venalainen., 2008, "Emission Trading and Climate Change Bulletin, McMillan Binch Mendelsohn LLP, Canada.

Institute for Global Environmental Strategis (IGES), 2011, “Clean Development Mechanism (CDM) in Indonesia, http://www.iges.or.jp, Accessed 8 July 2011.
Kementerian Lingkungan Hidup (KLH)., 2002, "National Strategy Study on the Clean Development

Mechanism in Indonesia, State Ministry for Environment Republic of Indonesia, Jakarta.

Kementerian Lingkungan Hidup (KLH)., 2009, "Indonesia Second National Communication Under The United Nations Framework Convention on Climate Change (UNFCCC)", The State Minister of Environment Republic of Indonesia, Jakarta

Kumar, R., 2005, "Research Methodology a Step by Step for Beginners, Second Edition ed, London,

Sage Publisher. Ministry of the Environment Japan., IGES., Ministry of Environment Republic of Indonesia., Carbon and Environmental Research (CER) Indonesia, 2006, "CDM Country Guide for Indonesia,

Japan. Napitupulu, T., O. Tanujaya., M.H. Soejachmoen., 2005, "CDM Development in Indonesia, Yayasan Pelangi, Jakarta.

PTNNT, Departemen Pengembangan Masyarakat, 2009, "Rencana Strategis Pengembangan Masyarakat di Kecamatan Maluk, Jereweh dan Sekongkang 2009-2013, Departemen Pengembangan Masyarakat PT Newmont Nusa Tenggara, ISBN 978602-8487-00-9.

Verchot, L.V., E. Petkova, K. Obidzinski., S. Atmadja., E.L. Yuliani., A. Dermawan., D. Murdiyarso., and S. Amira., 2010, "Reducing Forestry Emission in Indonesia", CIFOR, Bogor, Indonesia. ebut. 